\title{
Comparison of Muscodor albus Volatiles with a Biorational Mixture for Control of Seedling Diseases of Sugar Beet and Root-Knot Nematode on Tomato
}

\author{
E. Grimme and N. K. Zidack, Department of Plant Sciences and Plant Pathology, Montana State University, Boze- \\ man 59717-3150; R. A. Sikora, Inst. für Pflanzenkrankheiten, University of Bonn, Nussallee 9, 53115 Bonn, Ger- \\ many; and G. A. Strobel and B. J. Jacobsen, Department of Plant Sciences and Plant Pathology, Montana State \\ University, Bozeman 59717-3150
}

\begin{abstract}
Grimme, E., Zidack, N. K., Sikora, R. A., Strobel, G. A., and Jacobsen, B. J. 2007. Comparison of Muscodor albus volatiles with a biorational mixture for control of seedling diseases of sugar beet and root-knot nematode on tomato. Plant Dis. 91:220-225.

A biorational synthetic mixture of organic components mimicking key antimicrobial gases produced by Muscodor albus was equivalent to the use of live M. albus for control of seedling diseases of sugar beet (Beta vulgaris) caused by Pythium ultimum, Rhizoctonia solani AG 2-2, and Aphanomyces cochlioides. The biorational mixture provided better control than the live M. albus formulation for control of root-knot nematode, Meloidogyne incognita, on tomato (Lycopersicon esculentum). The biorational mixture provided control of damping-off equal to a starch-based formulation of the live fungus for all three sugar beet pathogens, and significantly reduced the number of root-knot galls on tomato roots compared with a barley-based formulation. Rate studies with the biorational mixture showed that 2 and $0.75 \mu \mathrm{l} / \mathrm{cm}^{3}$ of soil were required to provide optimal control of Rhizoctonia and Pythium damping-off of sugar beet, respectively. Five microliters of biorational mixture per milliliter of water was required for $100 \%$ mortality in $24 \mathrm{~h}$ for Meloidogyne incognita in in vitro studies. In in vivo studies, $1.67 \mu \mathrm{l}$ of the biorational mixture $/ \mathrm{cm}^{3}$ of sand resulted in fewer root-knot galls than a Muscodor albus infested ground barley formulation applied at $5 \mathrm{~g} / \mathrm{liter}$ of sand.
\end{abstract}

Additional keywords: biological control, biorational formulation, soil fumigation

Soil fumigation in the United States is highly dependent on the use of methyl bromide-chloropicrin mixtures (MBC). These mixtures are highly efficacious preplant soil fumigants in field and greenhouse production for control of soilborne diseases, insects, nematodes, and weeds (28). Methyl bromide-containing products are currently being phased out due to their role in depletion of the ozone layer (37). The loss of methyl bromide products for preplant soil fumigation will seriously reduce options for controlling soilborne pathogens such as Pythium sp., Fusarium sp., Phytophthora sp., Rhizoctonia solani, Verticillium dahliae, and V. albo-atrum, and the root-knot nematode Meloidogyne incognita $(23,28,36)$. Current research on methyl bromide alternatives includes developing management systems utilizing alternative chemicals (2,10,12,23,35), solarization $(6,7,19,26)$, biofumigation with Brassica spp. (31,33), organic amendments $(1,5,16)$, and biological control $(8,20,29)$. Currently, these alternatives

Corresponding author: B. J. Jacobsen

E-mail: uplbj@montana.edu

Accepted for publication 19 September 2006.

DOI: 10.1094/PDIS-91-2-0220

(C) 2007 The American Phytopathological Society do not offer the broad-spectrum activity and efficacy of MBC.

Many fungal species are known to produce different concentrations of volatile organic compounds (VOC) (4). Dennis and Webster (11) demonstrated that Trichoderma sp. emit VOC that inhibit other fungi, whereas other wood inhabiting fungi generate volatile products that have little or no antimicrobial properties. Muscodor albus, isolate 620 (39), an endophytic fungus obtained from Cinnamomum zeylanicum Bl. in Honduras, produces a mixture of VOC that effectively inhibits and kills a wide range of microorganisms $(14,18,32)$. The control of microorganisms with volatiles produced by fungi such as Muscodor albus and Muscodor roseus (38) has been termed "mycofumigation" $(32,40,41)$. The VOC produced include chemicals in the following classes: alcohols, esters, ketones, acids, and lipids, all of which exhibit low toxicity to mammals and higher plants including representatives from the plant families Asteraceae, Chenopodiaceae, Cruciferae, Cucurbitaceae, Gramineae, Leguminaceae, Rosaceae, and Solanaceae $(22,24,34)$. In early experiments, each of these classes of VOC were examined separately for mycelial growth inhibition against a range of fungi, but no single class of VOC were as effective as the VOC mixture produced by M. albus (34).
Stinson et al. (32) introduced the biological management of soilborne pathogens using mycofumigation. Reductions of sugar beet (Beta vulgaris L.) diseases caused by the soilborne pathogens Aphanomyces cochlioides, $R$. solani, and $P$. ultimum were shown in greenhouse assays with $M$. albus and its close relative $M$. roseus $(15,32,38)$. In field experiments with $M$. albus, mycofumigation has reduced damping-off caused by A. cochlioides and $P$. ultimum (15). Mycofumigation reduced disease severity and soil colony forming units of $V$. dahliae on eggplants (Solanum melongena L.) and chrysanthemum (Chrysanthemum $\times$ grandiflorum (Ramat.) Kitam.) (15,32). Mycofumigation using Muscodor sp. is a new concept of soil fumigation with potential for application, and it is critical to understand the effects of the mycofumigant fungi and their VOC on plant pathogenic and beneficial organisms. Prior to this research, mycofumigation with $M$. albus had not been tested on any nematodes.

Synthetic mimics of natural pesticidal compounds are termed biorational or biochemical pesticides. Examples include various mitochondrial respiration inhibiting strobilurin class fungicides that mimic strobilurin A produced by Strobiluris tenacellus (Pers. Ex Fr.) Sing. (3) and fludioxonil that mimics an antibiotic from Pseudomonas sp. (21). Mycofumigation with $M$. albus is the first example of a potential biorational fumigant based on use of a fungus.

The objectives of this research were to determine if a synthetic mixture of components of $M$. albus VOC could result in control of soilborne pathogens of sugar beet and root-knot nematode on tomato (Lycopersicon esculentum Mill.) comparable to a live formulation of $M$. albus. The effects of mycofumigation with a biorational mixture based on M. albus VOC and $M$. albus on sugar beet damping-off caused by $A$. cochlioides, $P$. ultimum, and $R$. solani, and root-knot of tomato caused by Meloidogyne incognita are reported herein. The soilborne pathogens of sugar beet and the root-knot nematode were chosen as representatives of soilborne pathogens that have been traditionally controlled through preplant soil fumigation with MBC mixtures. The sugar beet pathosystem was chosen because assay protocols were es- 
tablished in our lab (32), and tomato was chosen for root-knot because it is an excellent host and suffers significant economic loss from this pest (25).

\section{MATERIALS AND METHODS}

Artificial mixture of volatile compounds of $M$. albus and storage. The VOC produced by $M$. albus were quantitatively and qualitatively determined using gas chromatography and mass spectroscopy $(13,34)$. The synthetic biorational mixture (Table 1) was made by using authentic standard chemicals, obtained from Sigma-Aldrich (St. Louis, MO), found in M. albus gases and propanoic acid esters that were synthesized in the Montana State University Chemistry Department under the supervision of G. A. Strobel (14). The components of the mixture were adjusted to the same proportions as the components identified in the naturally occurring VOC (13-15,34) (Table 1). The liquid artificial mixture was stored in vials at $-20^{\circ} \mathrm{C}$ until used.

Preparation of $M$. albus ground barley formulation. $M$. albus, isolate 620 , was grown and maintained in $10-\mathrm{cm}$ petri plates on potato dextrose agar (PDA, Difco Laboratories, Detroit, MI) at $23 \pm 1^{\circ} \mathrm{C}$ for 2 weeks. Fifteen 5-mm-diameter agar plugs were transferred into 2-liter flasks with 1 liter of autoclaved potato dextrose broth (PDB, Difco Laboratories) and placed on a rotary shaker $(250 \mathrm{rpm})$ for 2 weeks at $23 \pm 1{ }^{\circ} \mathrm{C}$. The ground barley formulation was prepared by adding $60 \mathrm{ml}$ of colonized PDB to mason jars containing $300 \mathrm{~g}$ of twice autoclaved barley (Hordeum vulgare L.). After growth on the substrate for 3 weeks at $23 \pm 1{ }^{\circ} \mathrm{C}$, the colonized seeds were dried for $48 \mathrm{~h}$ in a fume hood. The barley seeds were ground using a Waring blender, resulting in particles ranging from 30 to $1,500 \mu \mathrm{m}$ with a mean particle size of $300 \mu \mathrm{m}$, and stored in sealed plastic bags at $4^{\circ} \mathrm{C}$ until used.

Preparation of plant-pathogen and nematode inocula. Cultures of $R$. solani AG (Anastomosis Group) 2-2, A. cochlioides, and $P$. ultimum were grown and maintained in $10-\mathrm{cm}$ petri plates containing potato dextrose agar at $22 \pm 1{ }^{\circ} \mathrm{C}$. All of these isolates were obtained from sugar beets grown in Montana. Inoculum of $R$. solani was prepared as infested ground barley according to the methods of Ruppel et al. (30). Inoculum of $A$. cochlioides and $P$. ultimum was prepared by chopping 2week-old PDA cultures into 1- to 2-mm pieces with a sterile tool. The $R$. solani inoculum consisted of dormant mycelium, whereas the A. cochlioides and P. ultimum inocula consisted of mycelia, sporangia, and oospores.

Tomato roots with galls containing Meloidogyne incognita were obtained from Ken Barker, Department of Plant Pathology, North Carolina State University, and maintained on tomato in the greenhouse at
Montana State University. M. incognita juveniles (J2) were harvested from 'Delicious' tomato plants with established rootknot galls using modifications to the method of Hussey and Barker (17). Galled roots were homogenized in a Waring blender for $20 \mathrm{~s}$ in a small amount of tap water. This suspension was placed in a mason jar with $500 \mathrm{ml}$ of $1.5 \% \mathrm{NaOCl}$ and shaken vigorously for $3 \mathrm{~min}$, then poured into a large container with 4 to 5 liters of cold tap water. The entire solution was then poured through a series of sieves in the following order: 250, 100, 45, and 25 $\mu \mathrm{m}$. The eggs were collected on the $25-\mu \mathrm{m}$ sieve and transferred onto a tissue-covered screen and placed into a shallow covered dish for hatching. Water from the dish was passed through the $25-\mu \mathrm{m}$ sieve daily to collect juvenile hatchlings, which were then placed in tap water in a beaker with a stream of fresh air bubbling through the aqueous suspension.

Greenhouse bioassays for testing the efficacy of $M$. albus against soilborne pathogens. Greenhouse bioassays were designed to measure the efficacy of the gas producing fungus $M$. albus in stabileze formulation, a starch and corn-oil based formulation described by Quimby et al. (27) and the biorational mixture of the VOC found in gases produced by $M$. albus for control of $R$. solani, A. cochlioides, and P. ultimum on sugar beet (Beta vulgaris L.). All experiments were carried out in a greenhouse with $24^{\circ} \mathrm{C}$ day and $18^{\circ} \mathrm{C}$ night temperatures with a $16-\mathrm{h}$ photoperiod. The growing substrate (Bozeman silt loam: washed concrete sand:Canadian sphagnum peat, 1:1:1) used for all sugar beet experiments was sieved ( $2 \mathrm{~mm}$ mesh opening) and autoclaved at $121^{\circ} \mathrm{C}$ and at a pressure of $21 \mathrm{~kg} / \mathrm{cm}^{2}$ for $60 \mathrm{~min}$. For soil infestation, $5 \mathrm{~g}$ of ground barley inoculum of $R$. solani was mixed thoroughly in $1 \mathrm{~kg}$ of soil. One 2 -week-old colonized petri plate culture of A. cochlioides or $P$. ultimum was chopped into small pieces (1 to $2 \mathrm{~mm}$ ) with a sterile tool and mixed with $6.4 \mathrm{~kg}$ of soil.

Pathogen-infested soil was treated with either the stabileze formulation or the biorational formulation in $10-\mathrm{cm}$ petri plates. The stabileze formulation of $M$. albus was added at a rate of $0.5 \mathrm{~g}$ to $60 \mathrm{~cm}^{3}$ of pathogen-infested soil. This rate was based on in vivo results reported by Stinson et al. (32). The biorational fumigation treatment was added at a rate of $60 \mu \mathrm{l}$ of the biorational mixture into plastic minicups $(6 \mathrm{~mm}$ diameter), which were nestled with the top open into the middle of $60 \mathrm{~cm}^{3}$ of pathogen-infested soil in petri plates. Minicups were used to assure that only VOCs were in contact with the pathogen-infested soil. The dosage of the biorational mixture was based on previous in vitro observations showing the $\mathrm{LD}_{50}$ concentration of the mixture for microbe inhibition was 60 $\mu \mathrm{l} / 50 \mathrm{ml}$ of air space in a standard petri plate (34). For the pathogen controls, 60 $\mathrm{cm}^{3}$ of infested soil was placed in petri plates, and an equal volume of noninfested soil was used for the noninfested control. All petri plates were sealed with two layers of Parafilm (Pechiney Plastic Packaging, Inc., Neenah, WI) and stored for 1 week at $22 \pm 1{ }^{\circ} \mathrm{C}$ for fumigation. After the 1 -week fumigation period, the soil treatments were added as an approximately 0.6 -cm-thick layer $\left(60 \mathrm{~cm}^{3}\right)$ on top of $400 \mathrm{~cm}^{3}$ of autoclaved soil in $10-\mathrm{cm}$ plastic square pots (10 $\times 10 \times 8.6 \mathrm{~cm})$. Twenty-five sugar beet seeds (cv. Beta 8754) without fungicide seed treatment were placed on the mycofumigated, biorational fumigated, pathogen-infested, or nontreated soil layer, covered with approximately $1.0 \mathrm{~cm}\left(80 \mathrm{~cm}^{3}\right)$ of sterilized soil, and placed in a greenhouse with $22^{\circ} \mathrm{C}$ day, $18^{\circ} \mathrm{C}$ night temperature and a photoperiod of $16 \mathrm{~h}$. The pots of the treatments with the pathogens, A. cochlioides and $P$. ultimum, were placed in shallow saucers with standing water for 3 days to favor infection (32). Pots of the noninfested control were also placed in saucers for the same time period. Seedling establishment was monitored for 28 days after planting and expressed as percent nonvisibly diseased sugar beet seedlings of the total number of seeds that were planted. Both bioassays were arranged in randomized complete designs with five replications. Experiments with all pathogens were repeated two times. Statistical analysis of the data was conducted by analysis of variance (ANOVA) using the general linear model procedure of the SAS program (SAS Institute, Cary, NC). The treatment means were separated using Fisher's least significant difference test at $P=0.05$.

Testing different rates of $M$. albus biorational mixture for controlling $\boldsymbol{P}$. ultimum, $R$. solani, and Meloidogyne incognita. Soil fumigation was performed by adding $15,30,45,60,90$, or $120 \mu \mathrm{l}$ of

Table 1. Volatile organic components of Muscodor albus biorational mixture

\begin{tabular}{lr}
\hline Chemical compound & $\mathbf{\%}^{\mathbf{z}}$ \\
\hline Octane & 0.47 \\
Acetone & 1.36 \\
Acetic acid, methyl ester & 0.99 \\
Acetic acid, ethyl ester & 11.14 \\
Propanoic acid, 2-methylethyl ester & 3.03 \\
Propanol,2-methyl & 3.01 \\
1-Butanol, 3-methyl-, acetate & 32.47 \\
Propanoic acid, 2-methyl, & \\
$\quad$ 3-methylbutyl ester & 2.24 \\
1-Butanol, 3-methyl- & 33.58 \\
2-Nonanone & 0.60 \\
Propanoic acid, 2-methyl & 8.86 \\
Caryophyllene & 0.71 \\
Phenylethyl alcohol & 1.54 \\
\hline
\end{tabular}

${ }^{\mathrm{z}}$ Relative percentage of each compound used in the mixture was based on the gas chromatography and mass spectroscopy analysis of the volatiles produced by 10-day-old cultures of $M$. albus grown on potato dextrose agar. 
the biorational mixture into plastic minicups (6 mm diameter), which were nestled with the top open into the middle of 60 $\mathrm{cm}^{3}$ of pathogen-infested soil in petri plates. For the pathogen controls, $60 \mathrm{~cm}^{3}$ of infested soil were placed in petri plates, and an equal volume of noninfested soil was used for the noninfested control. All petri plates were sealed with two layers of Parafilm and stored for 1 week at $22 \pm 1{ }^{\circ} \mathrm{C}$ for fumigation. The methods, experimental design, and statistical analysis following the fumigation period were similar to the methods described earlier. $\mathrm{EC}_{50}$ values were calculated from the linear regression model which was calculated using the REG procedure in the SAS program.

M. albus was grown on PDA in two of four quadrants of a four-quadrant segmented plate (VWR, West Chester, PA) for 7 days; $5 \mathrm{ml}$ of tap water was added to the other two quadrants. The plates were sealed with two layers of Parafilm and incubated for 5 days. Noninfested PDA was used as the nontreated control. After 5 days incubation at room temperature, ca. $25 \mathrm{M}$. incognita juveniles (J2) were added to each water-filled section. Mobility of juveniles was assessed using visual observation for mobility after 24 and $72 \mathrm{~h}$, and 1 week. At each time, juveniles from each treatment replicate were collected using a 25- $\mu \mathrm{m}$ sieve, resuspended in fresh tap water, and evaluated for mobility after 30 min. The experimental design was a complete randomized block with five replicates, and the described experiment was repeated twice.

In vitro assays for nematicidal activity of volatile components from $M$. albus. Assays were performed by adding $1 \mathrm{ml}$ of fresh tap water containing ca. $50 \mathrm{Meloi}$ dogyne incognita juveniles (J2) to 24-well cell culture plates (Nalg Nunc International, Rochester, NY). The biorational mixture previously described was added to each well at a rate of 0 to $8 \mu \mathrm{l} / \mathrm{ml}$. Mobility of juveniles was assessed after 1,2, and 24 $h$. At each time, juveniles from each treatment were collected as described above and evaluated for mobility after $30 \mathrm{~min}$. The experimental design was a complete randomized block with three replicates, and the described experiment was repeated twice.

Table 2. Percent healthy sugar beet seedlings after 28 days following mycofumigation of soil infested with Rhizoctonia solani, Pythium ultimum, or Aphanomyces cochlioides using live Muscodor albus (stabileze formulation) or a biorational mixture of chemicals found in volatiles emitted by M. albus

\begin{tabular}{lccc}
\hline & \multicolumn{3}{c}{ Percent healthy seedlings } \\
\cline { 2 - 4 } Treatment & $\boldsymbol{R}$. solani ${ }^{\mathrm{y}}$ & P. ultimum & A. cochlioides \\
\hline Live $M$. albus-stabileze formulation, $0.008 \mathrm{~g} / \mathrm{cm}^{3}$ of soil & $94.4 \mathrm{a}^{\mathrm{z}}$ & $92.0 \mathrm{ab}$ & $88.8 \mathrm{ab}$ \\
Biorational chemical mixture, $1.0 \mu \mathrm{l} / \mathrm{cm}^{3}$ of soil & $89.2 \mathrm{a}$ & $77.2 \mathrm{~b}$ & $78.0 \mathrm{~b}$ \\
Pathogen-infested control & $71.2 \mathrm{~b}$ & $2.8 \mathrm{c}$ & $0.8 \mathrm{c}$ \\
Noninfested control & $98.4 \mathrm{a}$ & $97.6 \mathrm{a}$ & $93.6 \mathrm{a}$ \\
\hline
\end{tabular}

${ }^{y}$ Soil was infested as follows: $R$. solani, $5 \mathrm{~g}$ of dry ground barley inoculum $/ \mathrm{kg}$ soil; P. ultimum and A. cochlioides, one homogenized, completely colonized $10-\mathrm{cm}$ petri plate $/ 6.4 \mathrm{~kg}$ of soil.

${ }^{\mathrm{z}}$ Means followed by the same letter are not significantly different based on Fisher's LSD at $P=0.05$. There was no treatment-experiment interaction. age of healthy seedlings 28 days postplanting $(P=0.0001)$ relative to the $R$. solaniinfested control. Percent healthy seedlings was statistically equivalent to the noninfested control (Table 2). Mycofumigation of P. ultimum- or A. cochlioides-infested soil using live $M$. albus in the stabileze formulation and the biorational chemical mixture resulted in a greater percentage of healthy seedlings 28 days postplanting $(P$ $=0.0001)$ than the pathogen-infested controls. M. albus formulated as stabileze was equivalent to the noninfested control (Table 2). There were no significant differences in percentages of healthy seedlings between the $M$. albus stabileze formulation and the biorational chemical mixture treatment; however, the percentage of healthy seedlings in the biorational treatment was significantly lower than in the noninfested control.

The M. albus stabileze formulation resulted in stunted sugar beet seedlings 14 days after planting (E. Grimme, unpublished). However, no differences in growth were observed 21 and 28 days after planting when compared with seedlings grown in sterilized soils. No reduction of growth was observed for seedlings grown in the biorational fumigation treatment. This observation supports the suggestion that the stabileze formulation itself was affecting the seedling growth, not the Muscodor fungus (32) or VOC produced by the fungus.

The biorational mixture at rates of 0.5 , $0.75,1.0,1.5$, and $2 \mu \mathrm{l} / \mathrm{cm}^{3}$ of soil for fumigation of Pythium-infested soil resulted in significantly higher percentages of healthy seedlings 28 days postplanting $(P$ $=0.0001)$ relative to the $P$. ultimuminfested control with the rates 0.75 to 2 $\mu \mathrm{l} / \mathrm{cm}^{3}$ of soil being statistically equivalent (Table 3). Fumigation using $0.5 \mu \mathrm{l} / \mathrm{cm}^{3}$ of the biorational was statistically different from the P. ultimum control, but the percentage of healthy seedlings was significantly lower than in the noninfested control or in the treatments using higher rates. Stands in the $0.25 \mu \mathrm{l} / \mathrm{cm}^{3}$ rate were similar to the pathogen control. Based on our data, the $\mathrm{EC}_{50}$ for P. ultimum was calculated to be $0.5 \mu \mathrm{l} / \mathrm{cm}^{3}$ of soil.

Fumigation of $R$. solani-infested soil using the rates of $0.5,0.75,1.0,1.5$, and 2 $\mu \mathrm{l} / \mathrm{cm}^{3}$ of soil of the biorational mixture resulted in significantly higher percentages of healthy seedlings 28 days postplanting $(P=0.0001)$ relative to the pathogen control with the $2 \mu \mathrm{l} / \mathrm{cm}^{3}$ rate providing stands equivalent to the noninfested control (Table 3). The rate of $0.25 \mu \mathrm{l}$ of biorational mixture resulted in a significantly lower percentage of healthy seedlings compared with the other treatments, and was statistically similar to the pathogen control. For the control of $R$. solani, the $\mathrm{EC}_{50}$ was calculated to be $1.50 \mu \mathrm{l} / \mathrm{cm}^{3}$ of soil.

In $M$. albus petri plate assays, a greater percentage of Meloidogyne incognita ju- 
veniles in plates with Muscodor albus were inactive after 24 and $72 \mathrm{~h}$ and 1 week compared with juveniles from the control plates (Table 4). After 1 week, $100 \%$ of the juveniles were immobile and did not regain mobility after exposure to fresh water for 30 min compared with only $25 \%$ mortality in the control plates.

In the nematode experiment, varying concentrations of the biorational mixture, Meloidogyne incognita juveniles from all treatments ( 1 to $8 \mu \mathrm{l} / \mathrm{ml}$ ) immediately biorational mixture to assay wells compared with no curling in the water controls. These differences were not apparent at the 1 - and $2-\mu \mathrm{l} / \mathrm{ml}$ rates after $1 \mathrm{~h}$ and resuspension in water for $30 \mathrm{~min}$, whereas $56 \%$ were straight and immobile in the $3 \mu \mathrm{l} / \mathrm{ml}$ treatment and $100 \%$ straight and immobile in the 6- to $8-\mu \mathrm{l} / \mathrm{ml}$ treatments (Table 5). After $2 \mathrm{~h}$ exposure followed by resuspension in water for $30 \mathrm{~min}, 100 \%$ of the juveniles in the $5-\mu \mathrm{l} / \mathrm{ml}$ treatment were straight and immobile. After $24 \mathrm{~h}$ exposure followed by resuspension in water for 30 min, some motility returned in the 3 - and $4-\mu \mathrm{l} / \mathrm{ml}$ treatments, but in the $5-$ to $8-\mu \mathrm{l} / \mathrm{ml}$ treatments, $100 \%$ were straight and immobile (Table 5). The $\mathrm{EC}_{50}$ for $M$. incognita juveniles was $2.9 \mu \mathrm{l} / \mathrm{ml}$ and the $\mathrm{EC}_{90}$ was $5.54 \mu \mathrm{l} / \mathrm{ml}$.

In the tomato root-knot experiment, the biorational mixture reduced the average number of galls per plant by nearly $84 \%$ compared with the barley control (Table 6). While the M. albus barley formulation reduced the number of galls per root, it was not significantly different from the barley control $(P<0.05)$. Neither dry nor fresh root weights were affected by any treatment.

\section{DISCUSSION}

The chemical and beneficial biological properties of Muscodor sp. were described previously in vitro $(14,15,34)$ and in vivo $(15,18,32,40,41)$. The improved seedling health in the present study with the live $M$. albus stabileze formulation was similar to the results reported by Stinson et al. (32), and fumigation with the biorational chemical mixture resulted in similar disease curled in response to the addition of the

control over the 28-day test period. Comparison of live formulations of $M$. albus and the biorational chemical mixture for soil disinfestation is an important step for the development of large-scale field and greenhouse sanitation strategies. Based on results of these studies and others from our laboratory, the biorational mixture tested would be used on a broadcast basis at 1,120 liters/ha compared with $9,363 \mathrm{~kg} / \mathrm{ha}$ for the stabileze formulation of live $M$. albus. These rates stand in comparison to 701.2 liter/ha (highest labeled rate for all crops) for the widely used soil fumigant Vapam HL (sodium methyldithiocarbamate; AMVAC, Los Angles, CA) or $392 \mathrm{~kg} / \mathrm{ha}$ (highest labeled rate for all crops) for the granular soil fumigant Basamid (tetrahydro-3,5,-dimethyl-2H1,3,5-thiadiazine-2-thione; BASF Corp., Research Triangle Park, NC). The above rates for the commercially formulated products are for control of soilborne fungi such as $R$. solani and P. ultimum and for root-knot nematodes including Meloidogyne incognita. While the rates for the biorational mixture or the stabileze formulation of Muscodor albus reported herein are much higher than comparable registered chemical fumigants, we have not yet attempted to examine the lowest efficacious rate of either the biorational or stabileze formulation for use in field soils. Ezra and Strobel (14) reported that the use of $0.26 \mu \mathrm{l}$ of the biorational mixture per cubic centimeter of air space provided $100 \%$ mortality of $R$. solani and P. ultimum in in vitro studies. In addition, Ezra et al. (13) and Ezra and Strobel (14) demonstrated the effective range of $M$. albus VOC to be between 100 and $200 \mathrm{ppb}$. Thus, it may be possible to reduce the rate of the biorational formulation by as much as $43 \%$, although a lower reduction might be possible in soil. The use of the biorational formulation eliminates the consideration of introducing a nonindigenous fungus into soils, and the rates used appear to be within the realm of feasibility. In addition, the use of the biorational mixture eliminates the variability associated with live formulations of $M$. albus, which were greatly affected by storage time and tem-

Table 3. Percent healthy sugar beet seedlings after 28 days following mycofumigation of soil infested with Rhizoctonia solani or Pythium ultimum using the Muscodor albus biorational mixture

\begin{tabular}{lcc}
\hline \multirow{2}{*}{$\begin{array}{l}\text { Concentration of } \boldsymbol{M} \text {. albus } \\
\text { biorational mixture }\left(\boldsymbol{\mu l} / \mathbf{c m}^{\mathbf{3}} \text { of soil }\right)\end{array}$} & \multicolumn{2}{c}{ Percent healthy seedlings } \\
\cline { 2 - 3 } & $\boldsymbol{P .}$ ultimum & $\boldsymbol{R}$. solani \\
\hline 2.00 & $93.2 \mathrm{a}^{\mathrm{z}}$ & $75.2 \mathrm{ab}$ \\
1.50 & $92.4 \mathrm{a}$ & $67.6 \mathrm{bc}$ \\
1.00 & $94.4 \mathrm{a}$ & $56.4 \mathrm{c}$ \\
0.75 & $91.6 \mathrm{a}$ & $38.8 \mathrm{~d}$ \\
0.50 & $52.0 \mathrm{~b}$ & $36.0 \mathrm{de}$ \\
0.25 & $6.0 \mathrm{c}$ & $24.0 \mathrm{ef}$ \\
Pathogen-infested control & $6.4 \mathrm{c}$ & $22.4 \mathrm{f}$ \\
Noninfested control & $90.8 \mathrm{a}$ & $84.8 \mathrm{a}$ \\
\hline
\end{tabular}

${ }^{\mathrm{y}}$ Soil was infested as follows: $R$. solani, $5 \mathrm{~g}$ of dry ground barley inoculum $/ \mathrm{kg}$ soil; P. ultimum, one homogenized, completely colonized $10-\mathrm{cm}$ petri plate $/ 6.4 \mathrm{~kg}$ of soil.

${ }^{\mathrm{z}}$ Means followed by the same letter are not significantly different based on Fisher's LSD at $P=0.05$. perature (15). In our studies, we have noted a greater than $50 \% \mathrm{CFU} / \mathrm{g}$ reduction in the stabileze formulation even when stored at -4 or $4^{\circ} \mathrm{C}$ for 6 months (data not shown).

Mycofumigation with the fungus $M$. albus or the biorational mixture was effective in improving healthy seedling establishment in experiments with soils infested with A. cochlioides, $P$. ultimum, and $R$. solani. The treatment with live $M$. albus formulated as stabileze or the biorational chemical mixture resulted consistently in a significantly higher sugar beet seedling survival relative to the respective pathogen treatments. The biorational treatment was statistically as effective against the tested soilborne pathogens as the live fungus formulation. These results support the in vitro results of Strobel et al. (34) that the fungal mycelium was not responsible for microbial inhibition, but the VOC produced by M. albus were effective in killing or inhibiting the other microorganisms. It is interesting that the biorational mixture was equal to the noninfested control for Rhizoctonia damping-off but was statistically less effective for Pythium- and Aphanomyces damping-off. Whether this

Table 4. An in vivo assay of Muscodor albus volatile organic compounds on activity of $\mathrm{Mel}$ oidogyne incognita second-stage juveniles in an in vitro assay

\begin{tabular}{lllr}
\hline & \multicolumn{3}{c}{$\begin{array}{c}\text { Percent immobile } \\
\text { juveniles }^{\mathbf{y}}\end{array}$} \\
\cline { 2 - 4 } Treatment & $\mathbf{2 4} \mathbf{h}$ & $\mathbf{7 2 ~ h}$ & $\mathbf{1}$ week \\
\hline $\begin{array}{c}\text { Noninfested } \\
\text { control (PDA) }\end{array}$ & $12 \mathrm{a}^{\mathrm{z}}$ & $21 \mathrm{a}$ & $25 \mathrm{a}$ \\
Muscodor albus & $31 \mathrm{~b}$ & $74 \mathrm{~b}$ & $100 \mathrm{~b}$ \\
\hline
\end{tabular}

${ }^{y}$ Nematode juveniles were observed using a dissecting scope and recorded as mobile or immobile.

${ }^{\mathrm{z}}$ Means followed by the same letter are not significantly different based on Fisher's LSD at $P=0.05$.

Table 5. Effect of volatile compound concentrations produced by Muscodor albus on viability of Meloidogyne incognita second-stage juveniles

\begin{tabular}{lcrr}
\hline \multirow{2}{*}{$\begin{array}{l}\text { Treatment } \\
\text { concentration }\end{array}$} & \multicolumn{3}{c}{ Percent immobile juveniles } \\
\cline { 2 - 4 } & $\mathbf{1 ~ h}$ & $\mathbf{2 ~ h}$ & $\mathbf{2 4} \mathbf{~ h}$ \\
\hline 0 & $0 \mathrm{~d}^{\mathrm{z}}$ & $0 \mathrm{~d}$ & $0 \mathrm{~d}$ \\
$1 \mu \mathrm{l} / \mathrm{ml}$ & $0 \mathrm{~d}$ & $0 \mathrm{~d}$ & $0 \mathrm{~d}$ \\
$2 \mu \mathrm{l} / \mathrm{ml}$ & $0 \mathrm{~d}$ & $0 \mathrm{~d}$ & $0 \mathrm{~d}$ \\
$3 \mu \mathrm{l} / \mathrm{ml}$ & $56 \mathrm{c}$ & $73 \mathrm{c}$ & $26 \mathrm{c}$ \\
$4 \mu \mathrm{l} / \mathrm{ml}$ & $83 \mathrm{~b}$ & $89 \mathrm{~b}$ & $63 \mathrm{~b}$ \\
$5 \mu \mathrm{l} / \mathrm{ml}$ & $94 \mathrm{~b}$ & $100 \mathrm{a}$ & $100 \mathrm{a}$ \\
$6 \mu \mathrm{l} / \mathrm{ml}$ & $100 \mathrm{a}$ & $100 \mathrm{a}$ & $100 \mathrm{a}$ \\
$7 \mu \mathrm{l} / \mathrm{ml}$ & $100 \mathrm{a}$ & $100 \mathrm{a}$ & $100 \mathrm{a}$ \\
$8 \mu \mathrm{l} / \mathrm{ml}$ & $100 \mathrm{a}$ & $100 \mathrm{a}$ & $100 \mathrm{a}$ \\
\hline
\end{tabular}

${ }^{y}$ Nematode juveniles were observed using a dissecting scope and recorded as mobile or immobile. Immobile juveniles failed to regain activity after resuspension in fresh tap water.

${ }^{z}$ Means followed by the same letter are not significantly different based on Fisher's LSD at $P=0.05$. 
is a statistical effect or a reflection that the biorational mixture was not equivalent to the live $M$. albus gases is unknown at this time. It is possible that other components of the gases produced by live $M$. albus are effective on these nonfungal pathogens. In addition to the volatile antimicrobial compounds produced by $M$. albus, we have evidence that water-soluble antimicrobial compounds also are produced. In well plate assays, $P$. ultimum is strongly inhibited and sometimes killed by water-soluble filter-sterilized compounds produced by $M$. albus (N. K. Zidack, unpublished). This implies that mycofumigation with $M$. albus may have a broader spectrum of activity than can be explained by the activity of the VOCs alone.

The lethal effect of gases produced by M. albus on Meloidogyne incognita juveniles (J2) came as somewhat of a surprise. Daisy and colleagues (9) demonstrated that a related organism, Muscodor vitigenus, produces naphthalene and has repellant activity against wheat stem sawfly larvae (Cephus cinctus). M. vitigenus produces significantly more naphthalene than $M$. albus, but has very little activity against Meloidogyne incognita juveniles (data not presented), while gases produced by Muscodor albus proved lethal to Meloidogyne incognita juveniles after $24 \mathrm{~h}$ exposure. The biorational mixture of VOCs proved to be acutely toxic to $M$. incognita, killing $100 \%$ of nematode juveniles at $2 \mathrm{~h}$ when applied in a $5-\mu \mathrm{l} / \mathrm{ml}$ aqueous solution. The same concentration applied in a drench in root-knot tomato pot assays was significantly more effective than incorporation of the live Muscodor albus alone.

It should be pointed out that the biorational mixture, stabileze, and ground barley formulations do not contain the same spectrum of VOCs found in $M$. albus VOCs produced on PDA (14). This is not unexpected since the spectrum of VOC produced is greatly affected by the substrate on which M. albus is grown (14). While exhaustive research as to the optimal formulation of a biorational mixture has not been completed, the biorational formulation described in these experiments contains compounds such as 1-butanol, 2 methyl; 1, butanol, 2-methyl acetate; propanoic acid; and 2-methyl-, 2-methyl propyl ester found in the VOCs produced by the live $M$. albus. Work is currently underway to optimize the antimicrobial activity of the biorational formulation, and it is clear from this work that a mixture of VOCs are necessary for activity approximating the VOCs produced by the live fungus.

The application of the M. albus biorational mixture in the field situation could be in the form of soil drenches or as injection-application with plastic cover as it is practiced with methyl bromide fumigation. It is possible that application rates could be reduced by using in-line row fumigation as opposed to broadcast fumigation since the VOCs are not phytotoxic. Future experiments will address the refinement of the biorational formulation and various formulations of live $M$. albus at various rates in the field. These experiments will provide information as to the practicality of mycofumigation or fumigation with a biorational formulation of $M$. albus-generated gases. We are also studying the toxicity of the water-soluble fungal products on a range of fungal pathogens.

Mycofumigation using Muscodor sp. or synthetic biorational mixtures of VOCs based on VOCs produced by the live fungus is a new concept of soil fumigation with potential broad application in the greenhouse and field. It is clear that mycofumigation or the use of $M$. albus based biorational formulations will not replace MBC since there will be no weed control. However, the use of live M. albus formulations or mimicking biorational formulations may provide control of important soil pathogens. On 22 September 2005, the US EPA granted a section 3 registration to AgraQuest (Davis, CA) for all soil and postharvest uses of M. albus. Due to the fact that methyl bromide and most of its chemical alternatives are extremely toxic to humans and animals, the relatively nontoxic nature of volatile gases of $M$. albus may promise to increase worker safety during soil fumigation and fewer adverse environmental effects $(32,36,37)$. Compared with chemical treatments, soil fumigation with $M$. albus might not need a waiting period before planting. M. albus might find its place also in integrated pest management in combination with crop rotation, solarization, application of beneficial microorganisms like Trichoderma sp., and other strategies.

\section{LITERATURE CITED}

1. Abbasi, P. A., Al-Dahmani, J., Sahin, F., Hoitink, H. A. J., and Miller, S. A. 2002. Effect of compost amendments on disease severity and yield of tomato in conventional and organic

Table 6. Effect of sterile barley, Muscodor albus barley formulation, and a biorational mixture based on the spectrum of volatiles produced by M. albus on root weight and galling of tomato by Meloidogyne incognita

\begin{tabular}{lccc}
\hline Treatment & $\begin{array}{c}\text { Fresh root } \\
\text { weight }(\mathbf{g})\end{array}$ & $\begin{array}{c}\text { Dry root } \\
\text { weight }(\mathrm{g})\end{array}$ & $\begin{array}{c}\text { No. of galls/ } \\
\text { root system }\end{array}$ \\
\hline Sterile barley control & $33.5 \mathrm{a}^{\mathrm{z}}$ & $3.6 \mathrm{a}$ & $63.0 \mathrm{a}$ \\
M. albus barley formulation $3 \mathrm{~g} /$ liter sand & $30.4 \mathrm{a}$ & $2.8 \mathrm{a}$ & $40.6 \mathrm{a}$ \\
Biorational mixture $5 \mu \mathrm{l} / \mathrm{cm}^{3}$ sand & $26.7 \mathrm{a}$ & $2.4 \mathrm{a}$ & $9.3 \mathrm{~b}$ \\
\hline
\end{tabular}

${ }^{\mathrm{z}}$ Means followed by the same letter are not significantly different based on Fisher's LSD at $P=0.05$. production systems. Plant Dis. 86:156-161

2. Ajwa, H. A., Trout, T., Mueller, J., Wilhelm, S., Nelson, S. D., and Shatley, D. 2002. Application of alternative fumigants through drip irrigation systems: Methyl bromide alternatives - meeting the deadlines. Phytopathology 92:1349-1355.

3. Anke, T., Oberwinkler, F., Steglich, W., and Schramm, G. 1977. The strobilurins-new antifungal antibiotics from the basidiomycete Strobilurus tenacellus (Pers. Ex Fr.) Sing. J. Antibiotics 30:806-810.

4. Bjurman, J., and Kristensson, J. 1992. Volatile production by Aspergillus versicolor as possible cause of odor in houses affected by fungi. Mycopathologia 118:173-178.

5. Chellemi, D. O., Mitchell, D. J., and Barkdol, A. W. 1992. Effects of composed organic amendments on the incidence of bacterial wilt of tomato. Proc. Fla. State Hortic. Soc. 105:364-366.

6. Chellemi, D. O., Olson, S. M., Mitchell, D. J., Secker, I., and McSorley, R. 1979. Adaption of soil solarization to the integrated management of soilborne pests of tomato under humid conditions. Phytopathology 87:250-258.

7. Coelho, L., Chellemi, D. O., and Mitchell, D. J. 1999. Efficacy of solarization and cabbage amendment for the control of Phytophthora spp. in North Florida. Plant Dis. 83:293-299.

8. Cuester, T. J. J., and Hoitink, H. A. J. 1999. Prospects for composts and biocontrol agents as substitutes for methyl bromide in biological control of plant diseases. Compost Sci. Utilization 7(3):6-15.

9. Daisy, B. H., Gary, A., Strobel, G. A., Castillo, U., Sears, J., Weaver, D. K., and Runyon, J. B. 2002. Naphthalene production by Muscodor vitigenus, a novel endophytic fungus. Microbiology 148:3737-3741.

10. De Cal, A., Martinez-Treceño, A., LopezAranda, J. M., and Melgarejo, P. 2004. Chemical alternatives to methyl bromide in Spanish strawberry nurseries. Plant Dis. 88:210-214.

11. Dennis, C., and Webster, J. 1971. Antagonistic properties of species of Trichoderma. II. Production of volatile antibiotics. Trans. Br. Mycol. Soc. 57:41-48.

12. Duniway, J. M. 2002. Status of chemical alternatives to methyl bromide for preplant fumigation of soil. Phytopathology 92:1337-1343.

13. Ezra, D., Jasper, J., Rogers, T., Knighton, B., Grimsrud, E., and Strobel, G. A. 2004. Proton transfer reaction-mass spectrometry as a technique to measure volatile emissions of Muscodor albus. Plant Sci. 166:1471-1477.

14. Ezra, D., and Strobel, G. A. 2003. Effect of substrate on the bioactivity of volatile antimicrobials produced by Muscodor albus. Plant Sci. 165:1229-1238

15. Grimme, E. 2004. Effects of mycofumigation using Muscodor albus and Muscodor roseus on diseases of sugar beet and chrysanthemum. M.S. thesis. Montana State University, Bozeman.

16. Hoitink, H. A. J., Inbar, Y., and Boehm, M. J. 1991. Status of compost-amended potting mixes naturally suppressive to soilborne diseases of floricultural crops. Plant Dis. 75:869873.

17. Hussey, R. S., and Barker, K. R. 1973. A comparison of methods of collecting inocula of Meloidogyne spp., including a new technique. Plant Dis. Rep. 12:1025-1028.

18. Jacobsen, B. J., Zidack, N. K., Strobel, G. A., Grimme, E., and Stinson, A. M. 2004. Mycofumigation with Muscodor albus for control of soil-borne microorganisms. Pages 12-25 in: Multitrophic interactions in soil. IOBC/wprs Bull. 27 (1).

19. Katan, J. 1996. Soil solarization: Integrated control aspects. Pages 250-278 in: Principles and Practice of Managing Soilborne Plant Pathogens. R. Hall, ed. American Phytopa- 
thological Society, St. Paul, MN.

20. Kurze, S., Bahl, H., Dahl, R., and Berg, G. 2001. Biological control of fungal strawberry diseases by Serratia plymuthica HRO-C48. Plant Dis. 85:529-534.

21. Leadbitter, N. J., Nyfeler, R., and Elmsheuser, H. 1994. The phenylpyrroles: The history of development at Ciba. Pages 129-134 in: BCPC monogr. no. 57 (1994) Seed treatment: Progress and prospects: Proceedings of a symposium organized by the British Crop Protection Council, and the Pesticides Group of the Society of Chemical Industry and held at the University of Kent, Canterbury on 5-7 January 1994. Trevor Martin, ed.

22. National Institute for Occupational Safety and Health. NIOSH Pocket Guide to Chemical Hazards (NPG). 2005. NIOSH Publications, N. E. Atlanta, GA.

23. Noling, J. W. 2002. The practical realities of alternatives to methyl bromide: Concluding remarks. Phytopathology 92:1373-1375.

24. O'Neil, M. J., Smith, A., Heckelmann, P. E., Obenchain, J. R., Jr., Gallipeau, J. A. R., D'Areccal, M. A., and Budavari, S. 2001. The Merck Index. 13th ed. Merck \& Co., Whitehouse Station, NJ.

25. Overman, A. J. 1991. Root-knot nematodes. Pages 49-50 in: Compendium of Tomato Diseases. J. B. Jones, J. P., Jones, R. E. Stall, and T. A. Zitter, eds. American Phytopathological Society, St. Paul, MN.

26. Pinkerton, J. N. 2002. The use of soil solarization for the management of soilborne plant pathogens in strawberry and red raspberry pro- duction. Plant Dis. 86:645-651.

27. Quimby, P. C., Jr., Zidack, N. K., Boyette, C. D., and Grey, W. E. 1999. A simple method for stabilizing and granulating fungi. Biocontrol Sci. Technol. 9:5-8

28. Raabe, R. D., Grebus, M. E., Wilen, C. A., and McCain, A. H. 2002. UC IPM Pest Management Guidelines - Floriculture and Ornamental Nurseries. University of California, UC ANR Publ. 3392, Davis, CA

29. Raupach, G. S., and Kloepper, J. W. 2000. Biocontrol of cucumber diseases in the field by plant growth-promoting rhizobacteria with and without methyl bromide fumigation. Plant Dis. 84:1073-1075.

30. Ruppel, E. G., Schneider, C. L., Hecker, R. J., and Hogaboam, G. J. 1979. Creating epiphytotics of Rhizoctonia root rot and evaluating for resistance to Rhizoctonia solani in sugar beet field plots. Plant Dis. Rep. 63:518-522.

31. Sarwar, M., Kirkegaard, J. A., and Wong, P. T. W. 1998. Biofumigation potential of brassicas. III. In vitro toxicity of isothiocyanates to soilborne pathogens. Plant Soil 201(1):103-112.

32. Stinson, A. M., Zidack, N. K., Strobel, G. A., and Jacobsen, B. J. 2003. Effect of mycofumigation with Muscodor albus and Muscodor roseus on seedling diseases of sugar beet and Verticillium wilt of eggplant. Plant Dis. 87:1349-1354.

33. Stirling, G. R., and Stirling, A. M. 2003. The potential of Brassica green manure crops for controlling root-knot nematode (Meloidogyne javanica) on horticultural crops in a subtropical environment. Aust. J. Exp. Agric.
43:623-630.

34. Strobel, G. A., Dirske, E., Sears, J., and Markworth, C. 2001. Volatile antimicrobials from Muscodor albus, a novel endophytic fungus. Microbiology 147:2943-2950.

35. Subbarao, K. V. 2002. Introduction. Methyl Bromide Alternatives - Meeting the Deadlines. Phytopathology 92:1334-1336.

36. U.S. Dep. Agric. 2002. The Status of Methyl Bromide Alternatives website. Online $\mathrm{Re}-$ sources.

37. U.S. Environmental Protection Agency (EPA) 2004. Questions \& Answers about Methyl Bromide Phaseout. Online Resources.

38. Worapong, J., Strobel, G. A., Daisy, B. H Castillo, U., Baird, G., and Hess, W. M. 2001. Muscodor roseus sp. nov. an endophyte from Grevillea pteridifolia. Mycotaxon 81:463-475.

39. Worapong, J., Strobel, G. A., Ford, E., Li, J. Y., and Hess, W. M. 2001. Muscodor albus anam. gen. et sp. nov., an endopythe from Cinnamomum zeylanicum. Mycotaxon 79:67-79.

40. Zidack, N. K., Grimme, E., Ezra, D., Stinson, A. M., Strobel, G. A., and Jacobsen, B. J. 2002. Progress in the development of mycofumigation for control of soil-borne plant diseases. Pages 38-42 in: Proc. 2002 Annu. Int. Conf. Methyl Bromide Alternatives Emissions Reductions USEPA/USDA, Washington, DC.

41. Zidack, N. K., Jacobsen, B. J., Stinson, A. M. and Strobel, G. A. 2001. Mycofumigation: A novel alternative to methyl bromide. Pages 361 in: Proc. 2001 Annu. Int. Conf. Methyl Bromide Alternatives Emissions Reductions. USEPA/USDA, Washington, DC. 